\title{
Ecological risk index for aquatic pollution control: a case study of coastal water bodies from the Rio de Janeiro State, southeastern Brazil
}

\section{Cristiane da Silveira Fiori ${ }^{1}$ \\ Ana Paula de Castro Rodrigues ${ }^{1 *}$ \\ Ricardo Erthal Santelli ${ }^{1}$ \\ Renato Campello Cordeiro' \\ Rodrigo Guerra Carvalheira ${ }^{1}$ \\ Patrícia Correa Araújo² \\ Zuleica Carmen Castilhos ${ }^{2}$ \\ Edison Dausacker Bidone ${ }^{1}$ \\ 'Department of Geochemistry, Universidade Federal Fluminense (UFF) - Niteroi (RJ), Brazil. \\ ${ }^{2}$ Center for Mineral Technology - (CETEM) - Rio de Janeiro (RJ), Brazil. \\ *Corresponding author: tantufaz17@gmail.com}

\begin{abstract}
The Potential Ecological Risk Index (PERI) was proposed by Håkanson in 1980 to be used as a diagnostic tool for water pollution. The aim of this study was to apply the PERI for tropical conditions, proposing modifications. The metal contamination of 15 areas, including five bays, from the coastal systems of the Rio de Janeiro State, Brazil, which present different pollution degrees and trophic status, was assessed. For environment sensitivity assessment through bioproduction estimation, the ratio of total phosphorus (in $\mathrm{mg} / \mathrm{g}$ )/organic matter in sediment (in \%) $\times 100$ was used, instead of the correlation between total nitrogen and organic matter as used in the original index calculation. The results for environment sensitivity were correlated with the concentration of acid volatile sulfides in sediments and with chlorophyll-a of the water column, showing a compatible relationship between water trophic status and sediment anoxia. The highest degree of contamination (DC) was found for the N-NW sector of the Guanabara bay (60.21 - classified as very high), followed by the Sepetiba bay stations, which showed DC values classified as moderate. The Ilha Grande bay and Paraty (Mamanguá) showed low DC values. The station of the Guanabara bay was the only one classified by the index as of very high ecological risk (PERI=697), followed by three stations classified as of moderate risk (Mouth of Guanabara bay; Garsas, Sepetiba bay; and Angra, Ribeira bay). All the other stations present low risk associated with metal exposure. As mercury is the metal of highest toxicity factor in the Håkanson formulation, a control test was applied to observe the relationship between PERI and mercury concentrations in fish and its bioconcentration factors, which are related to mercury bioavailability in the system. The results of the modified PERI were fully satisfactory for ranking areas of contamination.
\end{abstract}

Keywords: coastal systems, toxic metals, trophic status, sediments, fish.

\section{Resumo}

O Índice de Risco Ecológico Potencial (IREP) foi proposto por Håkanson, em 1980, para ser utilizado como ferramenta de diagnóstico de poluição da água. O objetivo deste estudo foi aplicar o IREP para condições tropicais, propondo modificações. Foi avaliada a contaminação por metais em 15 áreas, incluindo cinco baías, da costa do Estado do Rio de Janeiro, Brasil, que apresentam diferentes graus de poluição 
e trofia. Para avaliar a sensibilidade do meio, a partir da estimativa de bioprodução, foi usada a razão entre a concentração de fósforo total em sedimento (em $\mathrm{mg} / \mathrm{g}$ ) e o percentual de matéria orgânica em sedimento (em \%) x 100, ao invés da utilização da correlação entre nitrogênio total e matéria orgânica, conforme proposto originalmente para o cálculo do indice. Os resultados de sensibilidade do meio foram correlacionados com as concentrações de sulfetos voláteis em ácido em sedimentos e com a clorofila-a medida na coluna d'água, apresentando uma relação compativel entre o status de trofia da coluna d'água e a anoxia de sedimentos. O maior grau de contaminação (GC) foi encontrado no setor N-NO da Baía de Guanabara (60,21 - classificado como muito alto), seguido das estações localizadas na Baía de Sepetiba, que apresentaram GC classificado como moderado. A baía da Ilha Grande e Paraty (Mamanguá) apresentaram GCs baixos. A estação da Baía de Guanabara foi a única classificada pelo indice como risco ecológico potencial muito alto (IREP=697), seguida de três estações classificadas como risco moderado (boca da baía de Guanabara; Enseada das Garsas, na baía de Sepetiba; e Angra, na baía da Ribeira). Todas as outras estações apresentaram baixo risco associado à exposição por metais. O mercúrio é o metal com maior fator de toxicidade na formulação de Håkanson; então, um controle foi aplicado para observar a relação entre o IREP e as concentrações de mercúrio em peixes e seus fatores de bioconcentração, que são indicativos da biodisponibilidade do mercúrio no sistema. Os resultados do IREP modificado foram totalmente satisfatórios para o ranqueamento da contaminação das áreas estudadas. Palavras-chave: sistema costeiro, metais tóxicos, status de trofia, sedimentos, peixes.

\section{INTRODUCTION}

For an ecological risk assessment associated with pollutant exposure in aquatic ecosystems, several environmental factors must be considered, such as chemical, physicochemical, biological, and ecotoxicological parameters. All these variables must be integrated and some indexes have been applied to do it. The sediment quality triad, for example, was proposed originally by Long \& Chapman (1985) for risk assessment in estuarine and marine ecosystems, based on the relationship among measures of chemical contamination and ecotoxicity of sediments and resident infauna community. Abreu (2009) applied this index for some sectors of the Guanabara bay (State of Rio de Janeiro, Brazil), showing that the highest risks to biota were found in northwest and west sectors, especially at the area of Rio de Janeiro port.

Another index is the Potential Ecological Risk Index (PERI), proposed by Hakanson (1980), to be used as a quick and practical tool for environmental assessment, obtaining as results the pollution classification of areas and the identification of the toxic substances of interest, supporting actions for pollution control of limnic aquatic systems. The PERI provides a fast and simple quantitative value for the PER of a given contamination situation. The results have been tested on 15 Swedish lakes representing a wide range in terms of size, pollution, physicochemical characteristics (especially, $\mathrm{pH}$ ), and trophic status. This model, despite being formulated in 1980s and for limnic systems, has an organized structure based on simple algorithms, including the most important environmental parameters for an ecological risk assessment, and also includes the mathematical relationships between them.

The PERI is based exclusively on chemical parameters of sediments because sediment data show mean integrated values in time, with higher stability than water column parameters; sediments are easily sampled at field work; sediment samples are more representative for time and space scales and analytical data are easily obtained, especially because sediments present high concentrations of contaminants, decreasing the possible errors due to detection limits of the applied analytical method.

As proposed originally, the PERI considers four premises:

- the risk index increases with sediment contamination increase;

- $\quad$ higher the number of pollutants, higher the risk index;

- different substances show different toxicological risk levels;

- waters with different characteristics can show differences on sensitivity for toxic substances. 
Considering these premises, the main operational aspects to PERI estimation are:

- superficial sediments must be sampled in accumulation areas, that is, low energy areas;

- natural levels for toxic substances must be obtained using geological references or preindustrial levels determined using sediment cores;

- the metals included in the model are mercury $(\mathrm{Hg})$, cadmium $(\mathrm{Cd})$, lead $(\mathrm{Pb})$, cupper $(\mathrm{Cu})$, zinc $(\mathrm{Zn})$, and chromium (Cr). Polychlorinated biphenyls and arsenic (As) must be included if possible.

Previously, authors tested the PERI application in aquatic ecosystems of the Rio de Janeiro State, but no adaptation was suggested or calibration was conducted. Campos (2000)

\section{MATERIALS AND METHODS}

\subsection{Study areas}

The study was made at five bays from the coastal system of the Rio de Janeiro State (Brazil), with different degradation degrees (Figure 1): Guanabara bay - largely polluted; Sepetiba bay - has some contaminated areas; Ribeira bay - at initial state of degradation with punctual anthropogenic alterations; Ilha Grande bay - with intense tourism activity, however with well-preserved areas; and Paraty - more specifically, Mamanguá small cove, which preserves the properties of natural ecosystems.

The Guanabara bay $\left(22^{\circ} 24^{\prime}\right.$ to $23^{\circ} 57^{\prime} \mathrm{S} ; 42^{\circ} 33^{\prime}$ to $43^{\circ} 19^{\prime} \mathrm{E}$ ) is one of the largest bays of Brazil. The poor water quality of its affluent rivers (around 55), which drain the metropolitan region of the Rio de Janeiro city, is associated with the multiple anthropogenic activities that are developed at this drainage area $\left(4,198 \mathrm{~km}^{2}\right)$. More than 10 million habitants and around 12,000 industries are located at this drainage area, being distributed in 15 municipalities.

The most common environmental problems at the Guanabara bay are caused by unplanned occupation, intensive and inadequate use of natural resources, and/or inexistent or precarious treatment of sewage. The main causes for fluvial water quality degradation are deforestation, siltation, industrial effluents and domestic wastes without treatment, and solid residues. Sewage without treatment is responsible for more than $80 \%$ of pollutant discharge (approximately 460 tons of biochemical oxygen demand - BOD - per day), including micronutrients, toxic metals, and organic compounds (Bidone \& Lacerda, 2004).

The Sepetiba bay $\left(22^{\circ} 53^{\prime}\right.$ to $23^{\circ} 05^{\prime} \mathrm{S} ; 43^{\circ} 35^{\prime}$ to $\left.44^{\circ} 03^{\prime} \mathrm{W}\right)$ is a complex of estuarine system of high social, economical, and environmental importance. observed that the eutrophication of the Guanabara bay was able to reduce the PERI for metals, despite the high concentrations found in superficial sediments. Additionally, the highest risks were found for mercury and cadmium. Further, the PERI was tested for lagoons in the Rio de Janeiro State by Castilhos et al. (2001) and Fonseca (2002).

This study aimed to investigate the possibility of adaptation of PERI, a good idea as indicator, to an estuarine/ marine ecosystem with high dynamics, including superficial sediment resuspension, at tropical climate, testing the sensitivity of the index to classify five bays with different contamination degrees and trophic state of water column. This way, a simple index that uses a small number of variables could be used as tool for environmental management of degraded areas.
It has a watershed of $2,711 \mathrm{~km}^{2}$, with circa 1.7 million of habitants. One of the biggest port and industrial complexes of Brazil are located at its drainage area, and this complex continues arising at the present days. It receives high discharges of domestic wastes without treatment and of toxic metals from industrial activities (Molisani et al. 2004).

The Ribeira bay $\left(22^{\circ} 55^{\prime}\right.$ to $23^{\circ} 02^{\prime} S ; 44^{\circ} 18^{\prime}$ to $44^{\circ} 26^{\prime} \mathrm{W}$ ) has $120 \mathrm{~km}^{2}$ of superficial area. This bay is still well preserved; however the littoral occupation process during the last decade increased considerably, and actually there are punctual impacts caused by yards, marinas, and urban centers. The main activities are tourism, naval industry, and nuclear energy generation (two nuclear centrals, which use bay's waters to cool the reactors, being a third central built).

The Ilha Grande bay $\left(22^{\circ} 50^{\prime}\right.$ to $23^{\circ} 20^{\prime}$ S; $44^{\circ} 00^{\prime}$ to $44^{\circ} 45^{\prime} \mathrm{W}$ ) has a surface area of $1,120 \mathrm{~km}^{2}$. This bay is of spectacular beauty and its fauna and flora are rich, being a singular biodiversity sanctuary. It is located between the two largest metropolis of Brazil - São Paulo and Rio de Janeiro. The richness and diversity of species in this region is still weakly known and has origin on geographic and hydrographical conditions, allied to connectivity with coastal systems, organic matter from rivers, and physicochemical factors (Creed et al. 2007).

The Paraty - Mamanguá small cove $\left(23^{\circ} 10^{\prime}\right.$ to $23^{\circ} 23^{\prime} \mathrm{S}$; $44^{\circ} 30^{\prime}$ to $44^{\circ} 51^{\prime}$ W) - is part of an ecological reserve area. Mamanguá small cove has a high irregular coastal line, forming 33 small sand beaches linked by rocky shores. Only 120 families live in those beaches, with the same lifestyle of last generations, depending on the knowledge about forest and sea biodiversity for living. 
Figure 1

Location of the sampling stations at Guanabara, Sepetiba, Ribeira, and Ilha Grande bays and Paraty (Mamanguá small cove), Rio de Janeiro State, southeastern Brazil.

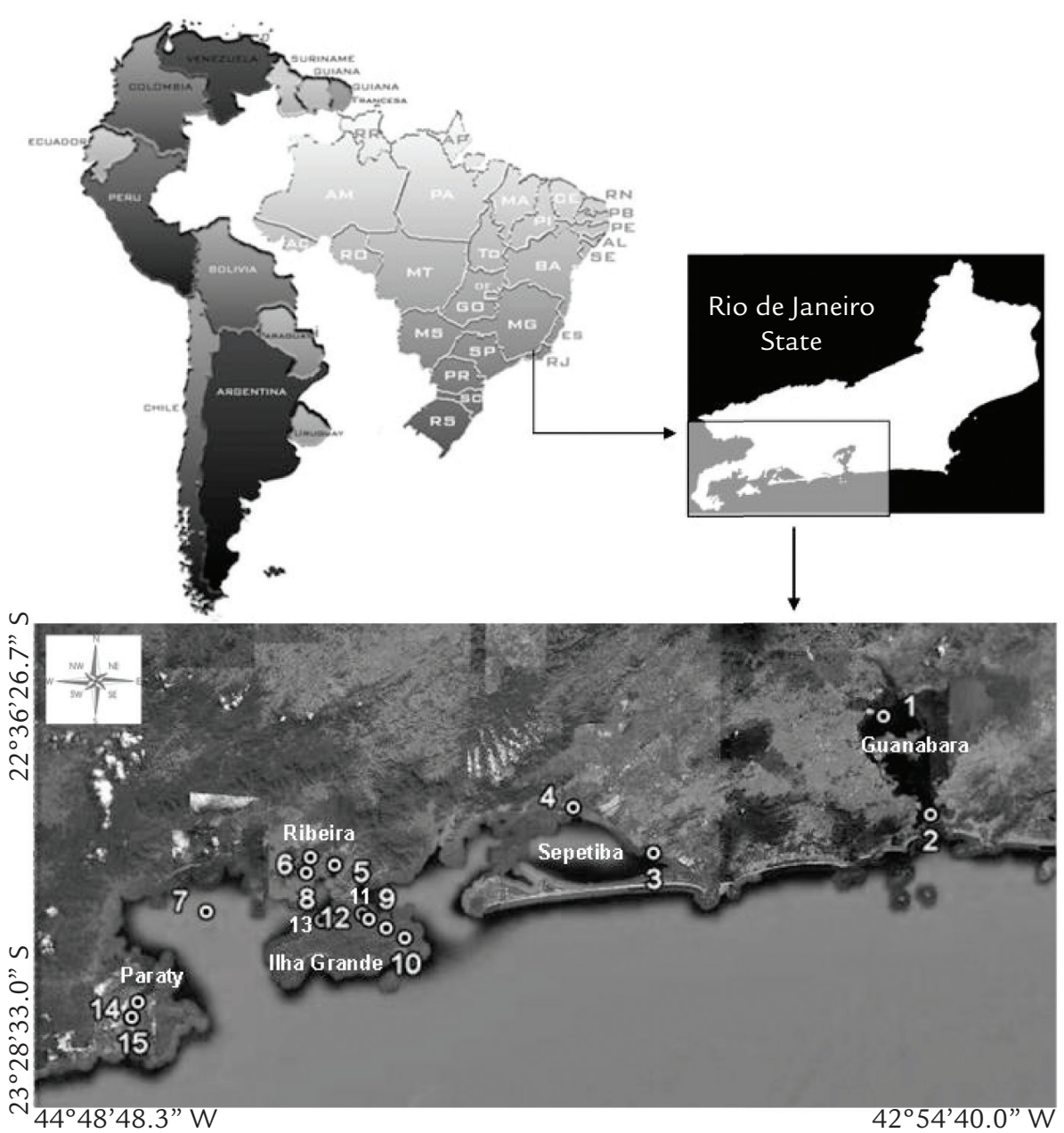

\subsection{Sampling and Analytical Procedures}

Superficial sediment was sampled at 15 accumulation points: two sample stations at the Guanabara bay; two at the Sepetiba bay; four at the Ribeira bay; five at the Ilha Grande bay, and two at the Mamanguá small cove. At each sample station, five samples were obtained using Eckman dredge, with an approximated area of $0.04 \mathrm{~m}^{2}$. The sample stations correspond to isolate coves, with profundity from around 5 to $20 \mathrm{~m}$.

For metal determination $(\mathrm{Cd}, \mathrm{Zn}, \mathrm{Cu}, \mathrm{Cr}$, and $\mathrm{Pb})$, sediment samples were pretreated according to US EPA 3051 method, using concentrated nitric acid in a microwave digester. The metal determination was conducted in inductively coupled plasma-optical emission spectrometer (ICP-OES), at Laboratory of Analytical Geochemistry, Geochemistry Department, Fluminense Federal University, Niterói, Brazil.

Total mercury $(\mathrm{HgT})$ determination was performed using LUMEX equipment (RA 915+), which is an atomic absorption coupled to a pyrolysis chamber, without pretreatment, only homogenization. These analyses were performed at the Laboratory for Environmental Mercury Speciation, Centre for Mineral Technology, Rio de Janeiro, Brazil.
As and PCB were not considered in this study. The results are presented as humid weight. Certified materials were used for equipment calibration.

Organic matter was determined using the method of lost for ignition, exposing the samples to $450^{\circ} \mathrm{C}$ during $24 \mathrm{~h}$. The total organic carbon (TOC) and total nitrogen (TN) were determined using an automatic $\mathrm{CHN}$ elemental analyzer. Total phosphorous (TP) concentrations were determined through the absorbency at $880 \mathrm{~nm}$, using calibration curve of dihydrogen potassium phosphate standard solutions, with measures in spectrophotometer (FEMTO, 700 PLUS model). These analyses were performed at Laboratory of Biogeochemistry, Geochemistry Department, Fluminense Federal University, Niterói, Brazil.

The procedures for acid volatile sulfide (AVS) analysis were adapted from the method described by Allen et al. (1993), and the analyses were performed at Laboratory of Environmental and Analytical Geochemistry, Geochemistry Department, Fluminense Federal University, Niterói, Brazil. Chl-a data were obtained from monitoring reports of the Environmental Agency of the Rio de Janeiro State (unpublished data). Results are listed in Tables 1 to 4. 


\subsection{Potential Ecological Risk Index Estimation}

PERI calculation as established by Håkanson (1980) is made using the following components:

(a) Contamination Factor (CF):

$\mathrm{CF}=\mathrm{C} / \mathrm{C}^{0}$,

where $\mathrm{C}$ is mean concentration of metal in sediment and $\mathrm{C}^{0}$ is background or preindustrial concentrations. For CF calculation, the background value was obtained from cores collected by the environmental agency of the Rio de Janeiro State (INEA - unpublished data). The classifications according to $\mathrm{CF}$ results are as follows:

\begin{tabular}{cc}
\hline Contamination Factor & Classification \\
\hline $\mathrm{CF}<1$ & Low \\
\hline $1 \leq \mathrm{CF}<3$ & Moderate \\
\hline $3 \leq \mathrm{CF}<6$ & Considerable \\
\hline $\mathrm{CF} \geq 6$ & Very high \\
\hline
\end{tabular}

The degree of contamination (DC) of one determined area is the sum of all CFs:

$\mathrm{DC}=\sum \mathrm{CF}$

The areas are classified according to DC as follows:

\begin{tabular}{cc}
\hline Degree of Contamination & Classification \\
\hline $\mathrm{DC}<1$ & Low \\
\hline $1 \leq \mathrm{DC}<3$ & Moderate \\
\hline $3 \leq \mathrm{DC}<6$ & Considerable \\
\hline $\mathrm{DC} \geq 6$ & Very high \\
\hline
\end{tabular}

(b) Toxic Response Factor (TRF): This depends on the sedimentological toxic factor (STF) and on sedimentological sensitivity factor (SSF).

(i) STF includes the toxicity variable, which must reflect the different toxic effects of each metal at natural aquatic systems. The toxicity values assigned by Håkanson were derived from three principles: abundance (more rare, more toxic is the metal); deposition (sink effect, measured using the ratio of metal concentration in water and metal concentration in sediment); and sizing principle (standardization and adjustment of abundance numbers, so that numbers may be used subsequently as STFs and be compared with the CFs). Since these principles, the following metals were classified in decreasing order of toxicity:

$\mathrm{Hg}=40>\mathrm{Cd}=30>\mathrm{Cu}=\mathrm{Pb}=5>\mathrm{Cr}=2>\mathrm{Zn}=1$.

(ii) SSF is related to the trophic status of the system, which influences the bioavailability of metals. In eutrophic aquatic eco- systems, metals are less bioavailable due to complexation effects and to biological dilution (Håkanson et al. 2003). In general, the negative effect of metals tends to increase with the bioproduction decrease. For SSF estimation, it is proposed to use correlations between nitrogen content and organic matter content (or loss on ignition) in bottom sediment samples, describing two characteristics of the regression line: the slope coefficient - BPN (bioproduction number) and the nitrogen content on the regression line for the organic matter content value of $10 \%$, called BPI (bioproduction index). The BPN-value could be an adequate sediment measure of the trophic level, but only when the organic content is less than $20 \%$ (Håkanson, 1984).

In this study, for SSF estimation, the relations among TN, TP, organic matter $(\mathrm{OM})$, and TOC were tested. TP and TOC were tested as alternative parameters to TN and OM, respectively. Due to the low number of samples (maximum five) that has been collected in each area, instead of regression curve construction for BPN or BPI calculation, the ratio among mean values of tested parameters for each area was used. Then, the previously described BPI and BPN were substituted by bioproduction ratio (BPR). The best responses were found using the ration among phosphorous and TOC, so BPR was calculated as follows:

$\mathrm{SSF}=\mathrm{BPR}=([\mathrm{TP}$ in $\mathrm{mg} / \mathrm{g}] /(\mathrm{TOC}$ in $\%) \times 100$

(iii) The TRF is calculated for each metal as follows:

$\mathrm{Hg}=40 \times 5 / \mathrm{BPR} ; \mathrm{Cd}=30 \times 5^{1 / 2} / \mathrm{BPR}^{1 / 2} ; \mathrm{Pb}=5 \times 5^{1 / 2} / \mathrm{BPR}^{1 / 2} ;$ $\mathrm{Cu}=5 \times 5^{1 / 2} / \mathrm{BPR}^{1 / 2} ; \mathrm{Cr}=2 \times 5^{1 / 2} / \mathrm{BPR}^{1 / 2} ; \mathrm{Zn}=1 \times 5^{1 / 2} / \mathrm{BPR}^{1 / 2}$.

(c) PER: PER $=$ TRF $\times$ CF, which is calculated separately for each metal. The classification according to PER results is as follows:

\begin{tabular}{cc}
\hline Potential Ecological Risk & Classification \\
\hline PER $<40$ & Low \\
\hline $40 \leq P E R<80$ & Moderate \\
\hline $80 \leq P E R<160$ & Considerable \\
\hline $160 \leq P E R<320$ & High \\
\hline PER $\geq 320$ & Very high \\
\hline
\end{tabular}

(d) PERI is the sum of all PER calculated for each metal inside one area: PERI $=\sum$ PER.

\begin{tabular}{cc}
\hline Potential Ecological Risk Index & Classification \\
\hline$P E R I<150$ & Low \\
\hline $150 \leq P E R I<300$ & Moderate \\
\hline $300 \leq P E R I<600$ & Considerable \\
\hline$P E R I \geq 600$ & Very high \\
\hline
\end{tabular}




\subsection{Correlations}

In anoxic sediments, degradation reactions mediated by microorganisms are less efficient and, consequently, the organic matter is not degraded so fast or as extensively as it occurs in toxic sediments (Canfield 1988). This process is more intense if the water column is also anoxic. In this way, the BPR results were calibrated using chlorophyll-a (Chl-a) concentrations in water and AVS in sediment samples. The Chl-a is a well- known indicator of trophic status of a water body, and AVS is an important indicator for anoxia that could be related to organic content and potential redox in sediments. When there is an increase of Chl-a and AVS values, metal bioavailability in water and sediments decreases. High concentrations of AVS allow metal retention in sediment at sulfite forms, being no longer bioavailable (Machado et al. 2004).

\section{RESULTS AND DISCUSSION}

\subsection{The contamination factor and the degree of contamination}

Mean values from superficial sediment from investigated areas for $\mathrm{Hg}, \mathrm{Cd}, \mathrm{Pb}, \mathrm{Cu}, \mathrm{Cr}$, and $\mathrm{Zn}$ are given in Table 1 as well as the background values, the calculated CF and $\mathrm{DC}$, and the ranking in descending order according to DC.

DC values characterize a decreasing gradient of pollution from north to south of the Rio de Janeiro State's littoral, reflect- ing the changes in soil occupation and the intensity of economic activities. The N-NW sector is the most contaminated of the Guanabara bay, and it shows the highest DC value of all studied areas (60.21 - classified as very high), followed by the Sepetiba bay stations, which show DC values classified as moderate. The Ilha Grande bay and Paraty (Mamanguá) show low DC values.
Table 1

Mean values from superficial sediment, contamination factors, degree of sediment contamination, and the degree of contamination ranking (descending order).

\begin{tabular}{|c|c|c|c|c|c|c|c|c|c|c|}
\hline Bay & Area & & $\mathrm{Hg}$ & $\mathrm{Cd}$ & $\mathrm{Pb}$ & $\mathrm{Cu}$ & $\mathrm{Cr}$ & Zn & DC & $\begin{array}{c}\text { DC } \\
\text { ranking }\end{array}$ \\
\hline & & Co & 0.05 & 0.60 & 10.50 & 4.10 & 21.80 & 60.00 & & \\
\hline \multirow[t]{6}{*}{ Guanabara } & $\begin{array}{l}\mathrm{N}-\mathrm{NW} \\
\text { sector }\end{array}$ & $\mathrm{Ci}$ & 1.06 & 0.82 & 58.00 & 59.90 & 270.00 & 308.00 & & \\
\hline & & $\mathrm{CFi}$ & 21.20 & 1.36 & 5.52 & 14.61 & 12.39 & 5.13 & 60.21 & 1 \\
\hline & & & vh & $\mathrm{m}$ & c & vh & vh & c & $\mathrm{Vh}$ & \\
\hline & Mouth/entry & $\mathrm{Ci}$ & 0.05 & 1.00 & 20.00 & 2.00 & 10.00 & 30.00 & & \\
\hline & & $\mathrm{CFi}$ & 1.00 & 1.67 & 1.90 & 0.49 & 0.46 & 0.50 & 6.02 & 9 \\
\hline & & & $\mathrm{m}$ & $\mathrm{m}$ & $\mathrm{m}$ & I & 1 & I & 1 & \\
\hline \multirow[t]{6}{*}{ Sepetiba } & Garças & $\mathrm{Ci}$ & 0.12 & 1.37 & 34.90 & 13.79 & 24.80 & 349.00 & & \\
\hline & & $\mathrm{CFi}$ & 2.43 & 2.28 & 3.32 & 3.36 & 1.14 & 5.82 & 18.36 & 3 \\
\hline & & & $\mathrm{m}$ & $\mathrm{m}$ & $c$ & c & $\mathrm{m}$ & c & $c$ & \\
\hline & Engenho & $\mathrm{Ci}$ & 0.20 & 2.41 & 87.71 & 21.32 & 47.00 & 732.00 & & \\
\hline & & CFi & 3.95 & 4.02 & 8.35 & 5.20 & 2.16 & 12.20 & 35.87 & 2 \\
\hline & & & c & c & vh & c & $\mathrm{m}$ & vh & vh & \\
\hline \multirow[t]{12}{*}{ Ribeira } & Jacuacanga & $\mathrm{Ci}$ & 0.06 & 0.61 & 16.75 & 12.50 & 22.00 & 102.00 & & \\
\hline & & CFi & 1.25 & 1.02 & 1.60 & 3.05 & 1.01 & 1.70 & 9.62 & 5 \\
\hline & & & $\mathrm{m}$ & $\mathrm{m}$ & $\mathrm{m}$ & c & $\mathrm{m}$ & $\mathrm{m}$ & $\mathrm{m}$ & \\
\hline & Angra & $\mathrm{Ci}$ & 0.07 & 0.79 & 15.21 & 9.17 & 27.00 & 120.00 & & \\
\hline & & $\mathrm{CFi}$ & 1.46 & 1.32 & 1.45 & 2.24 & 1.24 & 2.00 & 9.70 & 4 \\
\hline & & & $\mathrm{m}$ & $\mathrm{m}$ & $\mathrm{m}$ & $\mathrm{m}$ & $\mathrm{m}$ & $\mathrm{m}$ & $\mathrm{m}$ & \\
\hline & Ariró & $\mathrm{Ci}$ & 0.07 & 0.64 & 11.43 & 3.83 & 33.00 & 109.00 & & \\
\hline & & $\mathrm{CFi}$ & 1.34 & 1.07 & 1.09 & 0.93 & 1.51 & 1.82 & 7.76 & 7 \\
\hline & & & $\mathrm{m}$ & $\mathrm{m}$ & $\mathrm{m}$ & 1 & $\mathrm{~m}$ & $\mathrm{~m}$ & 1 & \\
\hline & Bracuí & $\mathrm{Ci}$ & 0.06 & 0.78 & 17.65 & 7.82 & 32.00 & 114.00 & & \\
\hline & & $\mathrm{CFi}$ & 1.19 & 1.30 & 1.68 & 1.91 & 1.47 & 1.90 & 9.44 & 6 \\
\hline & & & $\mathrm{m}$ & $\mathrm{m}$ & $\mathrm{m}$ & $\mathrm{m}$ & $\mathrm{m}$ & $\mathrm{m}$ & $\mathrm{m}$ & \\
\hline \multirow[t]{6}{*}{ Ilha Grande } & Palmas & $\mathrm{Ci}$ & 0.05 & 0.21 & 7.10 & 4.23 & 28.00 & 72.00 & & \\
\hline & & $\mathrm{CFi}$ & 1.02 & 0.35 & 0.68 & 1.03 & 1.28 & 1.20 & 5.56 & 11 \\
\hline & & & $\mathrm{m}$ & I & I & $\mathrm{m}$ & $\mathrm{m}$ & $\mathrm{m}$ & I & \\
\hline & Céu & $\mathrm{Ci}$ & 0.05 & 0.29 & 14.80 & 4.15 & 24.00 & 58.00 & & \\
\hline & & $\mathrm{CFi}$ & 1.01 & 0.48 & 1.41 & 1.01 & 1.10 & 0.97 & 5.98 & 10 \\
\hline & & & $\mathrm{m}$ & I & $\mathrm{m}$ & $\mathrm{m}$ & $\mathrm{m}$ & I & I & \\
\hline
\end{tabular}

Co: Background values for each metal; Ci: Concentration in superfitial sediments for each metal; CFi: Concentration factors for each metal; N-NW- north-northwest sector of Guanabara Bay; 1: low; m: moderate; c: considerable; vh: very high. 


\begin{tabular}{|c|c|c|c|c|c|c|c|c|c|c|}
\hline Bay & Area & & $\mathrm{Hg}$ & $\mathrm{Cd}$ & $\mathrm{Pb}$ & $\mathrm{Cu}$ & $\mathrm{Cr}$ & Zn & DC & $\begin{array}{c}\mathrm{DC} \\
\text { ranking }\end{array}$ \\
\hline & \multirow[t]{3}{*}{ Abraão } & $\mathrm{Ci}$ & 0.05 & 0.35 & 13.33 & 2.10 & 31.00 & 83.00 & & \\
\hline & & $\mathrm{CFi}$ & 1.10 & 0.58 & 1.27 & 0.51 & 1.42 & 1.38 & 6.27 & 8 \\
\hline & & & $\mathrm{m}$ & 1 & $\mathrm{~m}$ & 1 & $\mathrm{~m}$ & $\mathrm{~m}$ & $\mathrm{I}$ & \\
\hline & \multirow[t]{3}{*}{ Estrelas } & $\mathrm{Ci}$ & 0.05 & 0.26 & 13.40 & 2.73 & 28.00 & 76.00 & & \\
\hline & & $\mathrm{CFi}$ & 1.00 & 0.43 & 0.57 & 0.67 & 1.28 & 1.27 & 5.22 & 12 \\
\hline & & & $\mathrm{m}$ & I & 1 & I & $\mathrm{m}$ & $\mathrm{m}$ & I & \\
\hline & \multirow[t]{3}{*}{ Sítio Forte } & $\mathrm{Ci}$ & 0.06 & 0.15 & 5.10 & 0.42 & 13.00 & 29.00 & & \\
\hline & & $\mathrm{CFi}$ & 1.15 & 0.25 & 0.49 & 0.10 & 0.60 & 0.48 & 3.06 & 15 \\
\hline & & & $\mathrm{m}$ & 1 & 1 & 1 & 1 & 1 & 1 & \\
\hline \multirow[t]{6}{*}{ Paraty } & Mamanguá 1 & $\mathrm{Ci}$ & 0.05 & 0.09 & 11.74 & 0.30 & 8.30 & 57.00 & & \\
\hline & & $\mathrm{CFi}$ & 1.07 & 0.15 & 1.12 & 0.07 & 0.38 & 0.95 & 3.75 & 14 \\
\hline & & & $\mathrm{m}$ & I & $\mathrm{m}$ & 1 & 1 & 1 & 1 & \\
\hline & Mamanguá 2 & $\mathrm{Ci}$ & 0.05 & 0.17 & 13.79 & 1.86 & 1.30 & 62.00 & & \\
\hline & & $\mathrm{CFi}$ & 1.05 & 0.28 & 1.31 & 0.45 & 0.06 & 1.03 & 4.19 & 13 \\
\hline & & & $\mathrm{m}$ & 1 & $\mathrm{~m}$ & 1 & 1 & $\mathrm{~m}$ & 1 & \\
\hline
\end{tabular}

Table 1

Continuation
CF followed the same tendency found for DC, where the most contaminated areas (Guanabara and Sepetiba bays) were classified as considerable and very high; the Ribeira bay was classified as moderate and the Ilha Grande and Paraty as low. It is important to observe the total $\mathrm{Hg}$ results, which showed $\mathrm{CF}$, at minimum, moderate for all areas. Also, $\mathrm{Hg}$ represents one-third of DC value of N-NW sector at the Guanabara bay.
Besides the possibility of ranking the study areas according to DC, data summarized in the Table 1 allow to identify CF sequences, that is, which metal presented the highest enrichment factor in sediments. For example, for the Guanabara bay, the descending order of enrichment is: $\mathrm{Hg}>\mathrm{Cu}>\mathrm{Cr}>\mathrm{Pb}>\mathrm{Zn}>\mathrm{Cd}$.

\subsection{The sedimentological sensitivity factor and the bioproduction ratio}

For BPR choice, the ratios TN/OM, TN/TOC, TP/OM and TP/TOC were tested. In order to evaluate which ratio was capable of a better description of SSF, the following criteria were used: adherence of ratio values to bioproduction scale proposed for sediments and the relations between the tested ratios and the trophic status of water and sediment anoxia. For testing the last criteria, previously the relation among AVS (indicator of anoxia and proxy of redox potential in sediments) and Chl-a (indicator of trophic status of water) was evaluated. The AVS and Chl-a data showed positive correlation $(\mathrm{r}=0.677, \alpha=0.005)$, pointing to a com- patible relationship between water trophic status and sediment type as determined with AVS content from superficial sediment data.

Mean values of TN, TP, OM, TOC, AVS and Chl-a from superficial sediment are shown in Table 2. Using these data, the ratios TN/OM, TN/TOC, and TP/TOC were calculated. The original model proposed for PERI utilized TN and OM for sediment bioproduction determination. These attributes of sensibility were not efficient to classify areas in this study, probably because there are differences on material cycling among temperate and tropical regions.

\begin{tabular}{cccccccc}
\hline Bay & Area & $\begin{array}{c}\text { OM } \\
(\mathbf{\%})\end{array}$ & $\begin{array}{c}\text { TOC } \\
\mathbf{( \% )}\end{array}$ & $\begin{array}{c}\text { TP } \\
(\mathbf{m g} / \mathbf{g})\end{array}$ & $\begin{array}{c}\text { TN } \\
(\mathbf{m g} / \mathbf{g})\end{array}$ & $\begin{array}{c}\text { Chl-a } \\
(\mathbf{u g} / \mathbf{L})\end{array}$ & $\begin{array}{c}\text { AVS } \\
(\boldsymbol{\mu m o l} / \mathbf{g})\end{array}$ \\
\hline Guanabara & N-NW sector & 21.00 & 5.50 & 1.60 & 4.50 & 20.00 & 75.98 \\
\hline Sepetiba & Garças & 22.25 & 3.91 & 1.01 & 6.62 & 6.59 & 51.36 \\
\hline & Engenho & 19.89 & 3.78 & 0.80 & 6.41 & 4.22 & 56.41 \\
\hline Ribeira & Jacuacanga & 16.72 & 2.81 & 0.55 & 3.16 & 2.67 & 14.91 \\
\hline & Angra & 18.02 & 3.35 & 0.62 & 4.06 & 4.14 & 31.66 \\
\hline & Ariró & 16.63 & 2.79 & 0.56 & 3.18 & 3.64 & 9.93 \\
\hline Bracuí & 17.56 & 2.87 & 0.66 & 3.38 & 3.15 & 11.54 \\
\hline & Palmas & 14.95 & 1.83 & 0.44 & 2.06 & 1.62 & 3.30 \\
\hline Céu & 13.73 & 3.39 & 0.39 & 3.51 & 1.15 & 5.74 \\
\hline Abraão & 14.75 & 3.44 & 0.47 & 3.42 & 1.87 & 5.62 \\
\hline Estrelas & 14.26 & 3.27 & 0.41 & 3.52 & 1.29 & 25.06 \\
\hline Sartio Forte & 5.85 & 0.31 & 0.16 & 0.38 & 0.20 & 0.16 \\
\hline & Mamanguá 1 & 13.92 & 2.31 & 0.44 & 2.72 & 1.26 & 0.97 \\
\hline & Mamanguá 2 & 14.33 & 2.17 & 0.43 & 2.54 & 1.26 & 1.68 \\
\hline
\end{tabular}

Table 2

Mean values from superficial sediment for total nitrogen, total phosphorous, total organic carbon, organic matter, acid volatile sulfide (indicators of bioproduction in sediments) and Chl-a mean values (indicator of water trophic status). 
The nutrient flux on benthonic layer depends on, among others, temperature, organic matter deposition proportion, organic matter degradation integrated to mineralization in superficial and subsuperficial layers, denitrification, ion exchanges, and processes above and below oxicline. This flux tends to be higher at tropical regions due to high primary productivity and to higher deposition and consume of organic matter in median latitudes (Kennish, 1996). TN values of the studied areas are circa one fold higher than TN at lakes from the original study at Sweden. BPR values obtained using the equation $(\mathrm{TP} / \mathrm{OM}) \times 100$ were coherent with the original bioproduction scale, in dimension and classification (Table 3), possibly because phosphorous shows a conservative behavior, being more stable in marine environment than nitrogen (Souza \& Mayr, 1995).
Table 3

Comparative analysis between the water trophic status and the sedimentological bioproduction ratio.

\begin{tabular}{|c|c|c|c|c|c|c|c|}
\hline \multirow[t]{2}{*}{ Bay } & \multirow[t]{2}{*}{ Area } & \multicolumn{6}{|c|}{ Water trophic level (Chl-a) and sediment bioproduction ration } \\
\hline & & 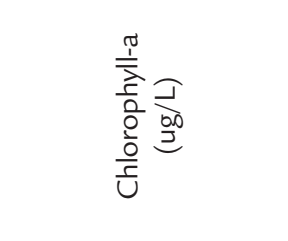 & 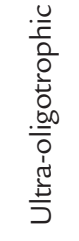 & $\begin{array}{l}\frac{u}{\frac{u}{2}} \\
0 \\
0 \\
\frac{0}{2} \\
0.00 \\
\frac{.00}{0}\end{array}$ & 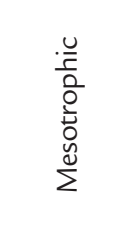 & 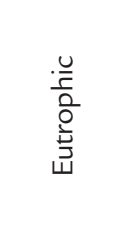 & 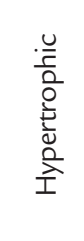 \\
\hline & & (average annual) (1) & $<1.0$ & $1.0-3.0$ & $3.0-8.0$ & $8.0-30.0$ & $>30.0$ \\
\hline & & Bioproduction (BPR) & & $<3.3$ & $<4.5$ & $<6.5$ & $>6.5$ \\
\hline \multicolumn{8}{|c|}{ (sediment level) (2) } \\
\hline \multicolumn{8}{|c|}{ Chl-a/BPR } \\
\hline Guanabara & N-NW sector & $20.00 / 7.6$ & & & & Chl-a & BPR \\
\hline \multirow[t]{2}{*}{ Sepetiba } & Garças & $6.59 / 4.6$ & & & Chl-a & BPR & \\
\hline & Engenho & $4.22 / 4.00$ & & & Chl-a/BPR & & \\
\hline \multirow[t]{4}{*}{ Ribeira } & Jacuacanga & $2.67 / 3.30$ & & Chl-a & BPR & & \\
\hline & Angra & $4.14 / 3.50$ & & & Chl-a/BPR & & \\
\hline & Ariró & $3.64 / 3.40$ & & & Chl-a/BPR & & \\
\hline & Bracuí & $3.15 / 3.70$ & & & Chl-a/BPR & & \\
\hline \multirow[t]{5}{*}{ Ilha Grande } & Palmas & $1.62 / 3.00$ & & Chl-a/BPR & & & \\
\hline & Céu & $1.15 / 2.90$ & & Chl-a/BPR & & & \\
\hline & Abraão & $1.87 / 3.20$ & & Chl-a/BPR & & & \\
\hline & Estrelas & $1.29 / 2.90$ & & Chl-a/BPR & & & \\
\hline & Sítio Forte & $1.20 / 2.80$ & & Chl-a/BPR & & & \\
\hline \multirow[t]{2}{*}{ Paraty } & Mamanguá 1 & $1.26 / 3.20$ & & Chl-a/BPR & & & \\
\hline & Mamanguá 2 & $1.26 / 3.00$ & & Chl-a/BPR & & & \\
\hline
\end{tabular}

Chl-a: Chlorophyll-a; BPR: bioproduction ratio.
The BPR and Chl-a of studied areas show positive correlation $(r=0.979, \alpha=0.001)$, demonstrating a compatible relationship between water trophic status and sediment type as determined with TP and OM contents in superficial sediments.
Another positive correlation was obtained for BPR and AVS $(\mathrm{r}=0.660, \alpha=0.005)$. At contaminated areas, sediments showed a higher BPR than the trophic status of water column indicated by Chl-a, probably reflecting the water renew character.

\subsection{The Potential Ecological Risk and the Potential Ecological Risk Index}

Table 4 summarizes TRF, SSF, and Potential Ecological Risk (PER) values and the results for PERI calculation at the studied areas. Data allow observing that:

- PER of Hg summed to PER of Cd corresponds to $80-90 \%$ of PERI at each area;

- $\quad$ PER of $\mathrm{Hg}$ corresponds to $50-80 \%$ of PERI at each area;

- Lower or higher PERI were obtained according to the weight of Hg PER for final PERI;

- Higher relative participation of Cd PER was found for the Sepetiba and Ribeira bays. There is a possibility of transference of Cd contamination from the Sepetiba bay to the Ribeira bay, as shown in Paraquetti et al. (2004). The Sepetiba bay is the second major receptor of industrial effluents of the Rio de Janeiro State, receiving significant amounts of $\mathrm{Hg}, \mathrm{Cd}, \mathrm{Pb}, \mathrm{Cu}$, and $\mathrm{Zn}$.

- $\quad$ SSF reduction (i.e., trophic status and bioproduction) cause an increment in PERI, proportionally. For example, if BPR of the Guanabara bay was three times higher, such as 2.5 , the environment would be classified as oligotrophic, and the resulting PERI would be approximately three times higher (around 1940 instead of 697);

- $\quad$ CF increment generates an equal increase of DC, since $\mathrm{DC}=\Sigma \mathrm{CF}$, but PERI increment will depend on which metal has this higher CF, because STF is a fixed value and it is specific for each one $(\mathrm{Hg}=40>\mathrm{Cd}=30>$ $\mathrm{Cu}=\mathrm{Pb}=5>\mathrm{Cr}>\mathrm{Zn}=1$ ). 
The results showed positive and significant correlations of PERI with DC ( $\mathrm{r}=0.979 ; \alpha=0.001)$, SSF, and BPR ( $\mathrm{r}=768$; $\alpha=0.001)$. Also, DC and SSF are correlated positively $(r=0.838$; $\alpha=0.001)$. These correlations, besides expressing the intern links among these components during PERI calculation, indicate that at these studied areas the responsible substances for SSF $(\mathrm{OM}, \mathrm{TP})$ and the considered metals have the same source or interdependent sources - for example, domestic wastes without treatment, deforestation, ports and shipyard installation.
The PERI application in estuarine and marine ecosystems was successful, demonstrating that the environmental variables used in the algorithm proposed by Hakanson (1980), with few modifications in sedimentological SSF, are the main integrator parameters for biogeochemical processes in aquatic ecosystems. Also, the relationship among these variables shows a logical synthesis of biogeochemical processes that influence metal behavior in the media (anoxia and/or productivity on superficial sediments).

\begin{tabular}{|c|c|c|c|c|c|c|c|c|c|}
\hline Bay & Area & & $\mathrm{Hg}$ & $\mathrm{Cd}$ & $\mathrm{Pb}$ & $\mathrm{Cu}$ & $\mathrm{Cr}$ & $\mathrm{Zn}$ & PERI \\
\hline \multirow[t]{6}{*}{ Guanabara } & N-NW sector & $\mathrm{SSF}=7.6$ & & & & & & & \\
\hline & & TRF & 26.3 & 24.3 & 4.1 & 4.1 & 1.6 & 0.8 & \\
\hline & & PER & $558(\mathrm{vh})$ & $33(\mathrm{I})$ & $22(\mathrm{I})$ & $59(\mathrm{~m})$ & $20(I)$ & $4(I)$ & 697 (vh) \\
\hline & Mouth/entry & $\mathrm{SSF}=2.1$ & & & & & & & \\
\hline & & TRF & 95.2 & 46.3 & 7.7 & 7.7 & 3.1 & 1.5 & \\
\hline & & PER & $95(c)$ & $77(\mathrm{~m})$ & $15(\mathrm{I})$ & $4(\mathrm{I})$ & $1(\mathrm{I})$ & $1(\mathrm{I})$ & $193(\mathrm{~m})$ \\
\hline \multirow[t]{6}{*}{ Sepetiba } & Garças & $S S F=4.6$ & & & & & & & \\
\hline & & TRF & 43.5 & 31.3 & 5.2 & 5.2 & 2.1 & 1.0 & \\
\hline & & PER & $106(c)$ & $71(\mathrm{~m})$ & $17(\mathrm{I})$ & $18(\mathrm{I})$ & $2(I)$ & $6(I)$ & $221(\mathrm{~m})$ \\
\hline & Engenho & $S S F=4.0$ & & & & & & & \\
\hline & & TRF & 50.0 & 33.5 & 5.6 & 5.6 & 2.2 & 1.1 & \\
\hline & & PER & $197(\mathrm{~h})$ & $135(c)$ & $47(\mathrm{~m})$ & $29(\mathrm{I})$ & $5(I)$ & $14(I)$ & 426 (c) \\
\hline \multirow[t]{12}{*}{ Ribeira } & Jacuacanga & $\mathrm{SSF}=3.3$ & & & & & & & \\
\hline & & TRF & 60.6 & 36.9 & 6.2 & 6.2 & 2.5 & 1.2 & \\
\hline & & PER & $76(\mathrm{~m})$ & $38(\mathrm{I})$ & $10(\mathrm{I})$ & $19(\mathrm{I})$ & $2(I)$ & $2(\mathrm{I})$ & $147(\mathrm{I})$ \\
\hline & Angra & $\mathrm{SSF}=3.5$ & & & & & & & \\
\hline & & TRF & 57.1 & 35.9 & 6.0 & 6.0 & 2.4 & 1.2 & \\
\hline & & PER & $84(c)$ & $47(\mathrm{~m})$ & $9(\mathrm{I})$ & $13(\mathrm{I})$ & $3(I)$ & $2(I)$ & $158(\mathrm{~m})$ \\
\hline & Ariró & $\mathrm{SSF}=3.4$ & & & & & & & \\
\hline & & TRF & 58.8 & 36.4 & 6.1 & 6.1 & 2.4 & 1.2 & \\
\hline & & PER & $79(\mathrm{~m})$ & $39(\mathrm{I})$ & $7(\mathrm{I})$ & $6(1)$ & $4(I)$ & $2(\mathrm{I})$ & $136(\mathrm{I})$ \\
\hline & Bracuí & $S S F=3.7$ & & & & & & & \\
\hline & & TRF & 54.1 & 34.9 & 5.8 & 5.8 & 2.3 & 1.2 & \\
\hline & & PER & $64(\mathrm{~m})$ & $45(\mathrm{~m})$ & $10(\mathrm{I})$ & $11(\mathrm{I})$ & $3(I)$ & $2(I)$ & $136(\mathrm{I})$ \\
\hline \multirow[t]{15}{*}{ Ilha Grande } & Palmas & $S S F=3.0$ & & & & & & & \\
\hline & & TRF & 66.7 & 38.7 & 6.5 & 6.5 & 2.6 & 1.3 & \\
\hline & & PER & $68(\mathrm{~m})$ & $14(\mathrm{I})$ & $4(I)$ & $7(\mathrm{I})$ & $3(I)$ & $2(I)$ & $97(\mathrm{I})$ \\
\hline & Céu & $\mathrm{SSF}=2.9$ & & & & & & & \\
\hline & & TRF & 69.0 & 39.4 & 6.6 & 6.6 & 2.6 & 1.3 & \\
\hline & & PER & $70(\mathrm{~m})$ & $19(\mathrm{I})$ & $9(\mathrm{I})$ & $7(\mathrm{I})$ & $3(\mathrm{I})$ & $1(\mathrm{I})$ & $109(\mathrm{I})$ \\
\hline & Abraão & $\mathrm{SSF}=3.2$ & & & & & & & \\
\hline & & TRF & 62.5 & 37.5 & 6.3 & 6.3 & 2.5 & 1.3 & \\
\hline & & PER & $69(\mathrm{~m})$ & $22(\mathrm{I})$ & $8(\mathrm{I})$ & $3(\mathrm{I})$ & $4(I)$ & $2(\mathrm{I})$ & $107(\mathrm{I})$ \\
\hline & Estrelas & $\mathrm{SSF}=2.9$ & & & & & & & \\
\hline & & TRF & 69.0 & 39.4 & 6.6 & 6.6 & 2.6 & 1.3 & \\
\hline & & PER & $69(\mathrm{~m})$ & $17(\mathrm{I})$ & $4(I)$ & $4(I)$ & $3(I)$ & $2(\mathrm{I})$ & $99(\mathrm{I})$ \\
\hline & Sítio Forte & $\mathrm{SSF}=2.8$ & & & & & & & \\
\hline & & TRF & 71.4 & 40.1 & 6.7 & 6.7 & 2.7 & 1.3 & \\
\hline & & PER & 82 (c) & $10(\mathrm{I})$ & $3(1)$ & $1(\mathrm{I})$ & $2(I)$ & $1(\mathrm{I})$ & $98(\mathrm{I})$ \\
\hline \multirow[t]{6}{*}{ Paraty } & Mamanguá 1 & $S S F=3.2$ & & & & & & & \\
\hline & & TRF & 62.5 & 37.5 & 6.3 & 6.3 & 2.5 & 1.3 & \\
\hline & & PER & $67(\mathrm{~m})$ & $6(1)$ & $7(\mathrm{I})$ & $0.5(\mathrm{I})$ & $1(\mathrm{I})$ & $1(\mathrm{I})$ & $82(I)$ \\
\hline & Mamanguá 2 & $S S F=3.0$ & & & & & & & \\
\hline & & TRF & 66.7 & 38.7 & 6.5 & 6.5 & 2.6 & 1.3 & \\
\hline & & PER & $70(\mathrm{~m})$ & $11(\mathrm{I})$ & $8(I)$ & $3(I)$ & $0.2(\mathrm{I})$ & $1(\mathrm{I})$ & $94(\mathrm{I})$ \\
\hline
\end{tabular}

SSF: sedimentological sensitivity factor; TRF: toxic response factor; PER: potential ecological risk; PERI: potential ecological risk index; 1: low; m: moderate; c: considerable; h: high; vh: very high.

Table 4 Results for Potential Ecological Risk Index. 
As a predict model, the PERI is dependent on calibration with bioindicators in order to evaluate its effectiveness for potential risk to biota, that is, in the case of calibration, the identification, characterization, and quantification of the toxic substance in organism tissues (exposure biomarkers) should be done. The central idea of this model is that the contaminant bioavailability is reduced when there is an increase in sediment anoxia and trophic

\subsection{Control Test}

For this evaluation, a carnivorous species was chosen - white mouth croaker (Micropogonias furnieri) — to represent the top of aquatic food chain and also because this species is well studied in four of the five bays in different time scale by several researchers. A summary of $\mathrm{Hg}$ concentrations in white mouth croakers is given in the Table 5 . Hg concentrations were grouped by length in order to null the possible influences on the results caused by differences on growth, which is essential for comparisons among areas. state of water column. So, the bioindicator must be related to both characteristics, that is, both matrixes (sediment and water). In this study as a control test, the bioavailability of mercury for one carnivorous fish species in all study areas was investigated. Mercury was chosen because it represents up to $80 \%$ of PERI values for almost all study areas, being representative of metal bioavailability and their risks in these areas.
All areas do not show significant differences in the $\mathrm{Hg}$ concentrations in fish muscles. At the Sepetiba bay, $\mathrm{Hg}$ concentrations in specimens $<300 \mathrm{~mm}$ and between 300 and $400 \mathrm{~mm}$ were similar, but they were different from the concentrations in fishes $>400 \mathrm{~mm}$. For the other bays (Guanabara and Ilha Grande), the accumulation seemed to be more linear, where all the three length intervals were different from each other, increasing levels with growth.

\section{Table 5}

Summary of total $\mathrm{Hg}$ concentrations (wet weight) in white mouth croaker (Micropogonias furnieri) from Rio de Janeiro estuaries, grouped in different length intervals.

\begin{tabular}{|c|c|c|c|}
\hline \multirow{2}{*}{ Reference } & \multicolumn{3}{|c|}{ Total Hg in muscles (ng/g) (w.w.) } \\
\hline & $<300 \mathrm{~mm}$ & $300-400 \mathrm{~mm}$ & $>400 \mathrm{~mm}$ \\
\hline \multicolumn{4}{|c|}{ Guanabara bay } \\
\hline Kehrig, 1992 & $45.4 \pm 21.7(16)$ & $116.6 \pm 45.9(31)$ & $165.7 \pm 46.1(14)$ \\
\hline Kehrig et al. 2002 & - & $108.9 \pm 58.6(61)$ & $199.5 \pm 119.3(20)$ \\
\hline Baeta, 2004 & - & $88 \pm 77(14)$ & - \\
\hline Rodrigues, 2006 & $56.8 \pm 13.0(14)$ & - & - \\
\hline Rodrigues et al. 2009 & $30.7 \pm 29.9(16)$ & - & - \\
\hline $\begin{array}{l}\text { Ratio of } \mathrm{Hg} \text { in fish } / \mathrm{Hg} \text { in } \\
\text { sediment }\end{array}$ & 0.04 & 0.09 & 0.17 \\
\hline \multicolumn{4}{|c|}{ Sepetiba bay } \\
\hline Kehrig, 1992 & $36.0 \pm 7.7(4)$ & $59.2 \pm 27.3(28)$ & $146.1 \pm 68.2(30)$ \\
\hline $\begin{array}{l}\text { Ratio of } \mathrm{Hg} \text { in fish/Hg in } \\
\text { sediment }\end{array}$ & 0.22 & 0.37 & 0.91 \\
\hline \multicolumn{4}{|c|}{ Ribeira bay } \\
\hline Rodrigues, 2006 & $65.2 \pm 45.8(32)$ & $81.9 \pm 52.9(2)$ & $536.1(1)$ \\
\hline $\begin{array}{l}\text { Ratio of } \mathrm{Hg} \text { in fish } / \mathrm{Hg} \text { in } \\
\text { sediment }\end{array}$ & 1.0 & 1.26 & 8.24 \\
\hline \multicolumn{4}{|c|}{ Ilha Grande bay } \\
\hline Kehrig, 1992 & $45.5 \pm 22.7(10)$ & $90.9 \pm 39.8(29)$ & $224.6 \pm 97.3(18)$ \\
\hline $\begin{array}{l}\text { Ratio of } \mathrm{Hg} \text { in fish } / \mathrm{Hg} \text { in } \\
\text { sediment }\end{array}$ & 0.91 & 1.82 & 4.49 \\
\hline
\end{tabular}

Comparing the means found for $\mathrm{Hg}$ in small specimens of white mouth croaker, it was observed that they have very close $\mathrm{Hg}$ levels. Only when they are $400 \mathrm{~mm}$ or larger than this, the increase in the $\mathrm{Hg}$ concentrations is evident and the difference among areas becomes clear, with higher $\mathrm{Hg}$ levels found for specimens from the Ilha Grande and Ribeira bays. However, it is important to highlight that only one specimen of this length was observed at the Ribeira bay, and then this value only can be used as example. In this way, $\mathrm{Hg}$ concentration in fish muscles from bays with oligotrophic characteristics (Ribeira and Ilha Grande bays) is significantly higher than the level found at eutrophic bays (Guanabara and Sepetiba).
Considering a scenario where $100 \%$ of $\mathrm{Hg}$ in sediment would be released to water and consequently bioavailable to benthonic fish, such as white mouth croaker (M. furnieri), and that this fish could absorb and accumulate this mercury form, the bioconcentration factor (BCF) could be used as a proxy of bioavailability. In Table 5, the ratios of mercury in fish muscles by mercury in sediments are listed for each area. For the ratio calculation, the mean values found for both parameters were used.

Observing the BCFs, the ratios increased for all length intervals in direction of oligotrophic areas. The ratios demonstrated that there is a higher bioavailability of $\mathrm{Hg}$ at oligotrophic areas such as Ilha Grande and Ribeira bays, 
being in agreement with the index premises. One could suggest that mercury in these areas is rapidly absorbed and accumulated by biota, reaching easily to carnivorous species like white mouth croakers. $\mathrm{Hg}$ concentrations in these fishes from these areas may be not even higher, because new/recent $\mathrm{Hg}$ input is low and $\mathrm{Hg}$ concentration in sediment is also low $(<50 \mathrm{ng} / \mathrm{g})$.

Additionally, the differences in BCFs obtained for $<300 \mathrm{~mm}$ and $>400 \mathrm{~mm}$ specimens are clear. For the Guanabara, Sepetiba, and Ilha Grande bays, the BCFs of $>400 \mathrm{~mm}$ specimens are four times higher than BCFs of $300 \mathrm{~mm}$ specimens $(4.25 ; 4.14 ; 4.93$, respectively). Only at the Ribeira bay, this difference was even higher (8.24).

Those results for BCFs demonstrated that $\mathrm{Hg}$ bioaccumulation occurs in different ways at the four studied areas. Previously, Rodrigues et al. (2010) demonstrated that bioaccumulation in the Ribeira bay was faster than in the Guanabara bay, using accumulation curves according to fish length, for the other two fish species - a catfish, Genidens genidens, and a grunt, Haemulon steindachneri. These species also showed higher BCFs ratios at the Ribeira bay (oligotrophic system) than at the Guanabara bay (eutrophic system).

Some biological and geochemical factors could be influencing the accumulation in the Ribeira bay, such as differences either in growth or in maturation, new $\mathrm{Hg}$ inputs linked to the increase of anthropogenic activities, and others. Comparing with PERI results, the concentration factors (CFs) of $\mathrm{Hg}$ in the Ribeira bay were classified as moderate. One could suggest that this oligotrophic

\section{CONCLUSIONS}

The PERI application for tropical areas — established initially for limnic systems at temperate climate conditions - can be considered as promising according to the results achieved at this work. Some adaptations in the original proposal were necessary for sediment sensitivity calculation, using the BPR, which is the relation among TP and OM. The BPR results correlated with trophic state and anoxia indicators (chlorophyll-a and AVS, respectively). These results also corroborate the findings related to metal bioavailability to trophic chain, exemplified by $\mathrm{Hg}$ concentrations in fish muscles in this study case, where the oligotrophic ecosystem showed higher mercury incorporation by fish than eutrophic areas.

The modifications on PERI calculation were capable of ranking coastal areas and their potential toxicity to biota. environment with a rising input of $\mathrm{Hg}$ and organic matter from untreated sewage is clearly transforming $\mathrm{Hg}$ to methylmercury, which is being transferred to food web faster than the other studied areas.

The Sepetiba bay, where $\mathrm{Hg}$ distribution is given mainly by fluvial sediment deposition, with posterior sulfide formation, seems to be an intermediate system, in comparison with the two extremes (Ilha Grande and Guanabara bays). Only for larger specimens of M. furnieri (>400 $\mathrm{mm}$ ) a proximity of fish and sediment concentrations (ratio close to 1) can be observed. At this environment, methylmercury could be formed by remobilization and oxidation of $\mathrm{Hg}$ associated with sulfides in sediment (Marins 1998). Comparatively, Hg concentration in sediment from the Sepetiba bay is one fold lower than sediments from northwest region of the Guanabara bay.

The BCF ratios can be used as proxies/indicators for $\mathrm{Hg}$ bioaccumulation, because the differences in mercury accumulation at the four studied areas were clearly demonstrated by them, emphasizing the higher accumulation in oligotrophic areas. It is also important to highlight that differences among areas were not clear before using those ratios. The differences were clear only for concentrations with larger than $400 \mathrm{~mm}$ specimens. Using the BCFs, it was possible to observe these differences even at smaller fish length intervals. There is a clear positive gradient between $\mathrm{BCF}$ and fish length at all bays. One could suggest that the $\mathrm{Hg}$ absorption increases with fish age at each area and that this accumulation is higher in oligotrophic bays, comparing fish with the same weight among bays.

The original premise proposed for PERI was, in general, confirmed - more eutrophic ecosystems have lower toxicological risks associated with metal bioavailability. The index results highlight $\mathrm{Hg}$ role and importance in the final results, defining the Guanabara bay as highly impacted. It also allows tracing an N-S environmental degradation gradient, beginning with the most impacted area at the northwest Guanabara bay until the Mamanguá small cove, which presents low ecological risk. However, it is necessary to emphasize that major studies about the index efficiency and a better calibration of this method in terms of bioavailability and accumulation by biota (including other metals) are extremely important to understand and to apply this index as a useful tool in managing coastal water resources.

\section{ACKNOWLEDGMENTS}

This work is part of the Instituto Nacional de Ciência e Tecnologia - INCT-TMCOcean, Universidade Federal do Ceará, Fortaleza, State of Ceará, Brazil. 


\section{REFERENCES}

Abreu I.M. 2009. Avaliação geoquímica, biológica e ecotoxicológica dos sedimentos da Baía de Guanabara - RJ. Tese de Doutorado, Departamento de Geoquímica, Universidade Federal Fluminense, Niterói-RJ, 120 p.

Allen H.E. 1993. Determination of Acid Volatile Sulfides and Selected Simultaneously Extractable Metals in Sediment. United States Environmental Protection Agency Report 821/12-91/100.

Baeta A.P. 2004. Mercúrio Total e Metilmercúrio em Diferentes Espécies de Peixes da Baía de Guanabara. Dissertação de Mestrado, Departamento de Química, Pontifícia Universidade Católica do Rio de Janeiro, Rio de Janeiro, 133 p.

Bidone E.D. \& Lacerda L.D. 2004. The use of DPSIR framework to evaluate sustainability in coastal areas. Case study: Guanabara Bay Basin, Rio de Janeiro, Brazil. Regional Environmental Change, 4(1):5-16.

Campos A.N. 2000. Ensaio de adaptação e utilização de um 'índice de risco ecológico potencial' para controle da contaminação por metais pesados em ambiente costeiro tropical: Baía de Guanabara, RJ - Brasil. Dissertação de Mestrado, Departamento de Geoquímica, Universidade Federal Fluminense, Niterói-RJ, 176 p.

Canfield D.E. 1988. Sulfate Reduction and the Diagenesis of Iron in Anoxic Marine Sediments. Tese de Doutorado, Yale University, Yale, 496 p.

Castilhos Z.C., Gonçalves G.O., Campos A., Bidone E.D. 2001. Potential Ecological Risk by Hg Contamination in Aquatic Ecosystems of Rio de Janeiro State, Brazil. In: International Conference on Mercury as a Global Pollutant, 6, Minamata, SP.

Creed J.C., Pires D.O., Figueiredo M.A.O. 2007. Biodiversidade Marinha da Baía da Ilha Grande. -Brasília - DF, Ministério do Meio Ambiente - MMA. Biodiversidade 23.

Fonseca M.C. 2002. Avaliação de índice de risco ecológico potencial para a contaminação por metais pesados, caso das lagunas do leste fluminense. Dissertação de Mestrado, Departamento de Geoquímica, Universidade Federal Fluminense, Niterói-RJ, 116 p.

Hakanson L. 1980. An ecological risk index aquatic pollution control. A sedimentological approach. Water Research, 14:975-1001.

Hakanson L. 1984. On the relationship between lake trophic level and lake sediments. Water Research, 18(3):303-314.

Hakanson L., Ostapenia A., Parparov A., Hambright K.D., Boulion V.V. 2003. Management criteria for lake ecosystems applied to case studies of changes in nutrient loading and climate change. Lakes \& Reservoirs: Research and Management, 8(2):141-155.

Kehrig H.A., Costa M., Moreira I., Malm O. 2002. Total and methylmercury in a Brazilian estuary, Rio de Janeiro. Marine Pollution Bulletin, 44:1018-1023.

Kehrig H.A. 1992. Estudo comparativo dos níveis de concentração de mercúrio total de corvinas (Micropogonias furnieri) de quatro estuários brasileiros. Dissertação de Mestrado, Departamento de Química, Pontifícia Universidade Católica do Rio de Janeiro Rio de Janeiro - RJ, 121 p.

Kennish M.J. 1996. Practical Handbook of Estuarine and Marine Pollution. Boca Raton, Florida, CRC Marine Science Series, 544 p.

Long E.R. \& Chapman P.M. 1985. A sediment quality triad: measures of sediment contamination, toxicity and infaunal community composition in Puget Sound. Marine Pollution Bulletin, 16:405415.

Machado W., Carvalho M.F., Santelli R.E., Maddock J.E.L. 2004. Reactive sulfides relationship with metals in sediments from an eutrophicated estuary in Southeast Brazil. Marine Pollution Bulletin, 49:89-92.

Marins R.V., Lacerda L.D., Paraquetti H.M., Paiva E.C., Villas-Boas R.C. 1998. Geochemistry of mercury in sediments of a sub-tropical coastal lagoon, 
Sepetiba Bay, Southeastern Brazil. Bulletin of Environmental Contamination and Toxicology, 61:57-64.

Molisani M.M., Marins R.V., Machado W., Paraquetti H.H.M., Bidone E.D., Lacerda L.D. 2004. Environmental changes in Sepetiba Bay, SE Brazil. Regional Global Change, 4:17-27.

OECD, Organization for Economic Co-Operation and Development. 2008. Probability Distribution Diagrams- Vollenweider's dictum. Disponível em: http://www.chebucto.ns.ca/ccn/info/Science/SWCS/TPMODELS/OECD/ probability.html. Acessado em 25 Set 2009.

Paraquetti H.H.M., Ayres G.A., Almeida M.D., Molisani M.M., Lacerda L.D. 2004. Mercury distribution, speciation and flux in the Sepetiba Bay tributaries, SE Brazil. Water Research, 38:1439-1448.

Rodrigues A.P.C. 2006. Avaliação de risco ecológico associado à contaminação mercurial em dois estuários do estado do Rio de Janeiro: Baía de Guanabara e Baía da Ribeira. Dissertação de Mestrado, Departamento de Geoquímica, Universidade Federal Fluminense, Niterói, 96 p.

Rodrigues A.P.C., Bidone E.D., Castilhos Z.C., Araújo P.C., Fernandes P.S., Almosny N.R.P., Linde-Arias A.R. 2009. Biacumulação de mercúrio em três espécies de peixes na Baía de Guanabara, RJ. In: International Symposium on Environmental Geochemistry, 8, Ouro Preto, S.P.

Rodrigues A.P.C., Carvalheira R.G., Cesar R.G., Bidone E.D., Castilhos Z.C., Almosny N.R.P. 2010. Bioacumulação de Mercúrio em Quatro Espécies de Peixes Tropicais Oriundos de Ecossistemas Estuarinos do Estado do Rio de Janeiro, Brasil. Anuário do Instituto de Geociências - UFRJ, 33(1):54-62.

Souza M.F.L. \& Mayr L.M. 1995. Nitrogen phosphorus and granulometric characterization in nearshore sediments of Guanabara Bay: tentative applications of a solid phase diagenetic model. Neritica, 9(1/2):7-18. 